\title{
EFEKTIFITAS PEMBERIAN REBUSAN DAUN ALPUKAT TERHADAP TEKANAN DARAH PENDERITA HIPERTENSI DI PUSKESMAS SIWALANKERTO SURABAYA
}

\author{
Naomiyah,Tyas Solit ${ }^{1}$, Sustrami,Dya ${ }^{2}$, Kirana, Sukma Ayu C. ${ }^{3}$ \\ ${ }^{1,2,3}$ Sekolah Tinggi Ilmu Kesehatan Hangtuah Surabaya
}

Korespondensi : tyasnaomi5@gmail.com

\begin{abstract}
Background: Hypertension is the highest cause of death in Indonesia. Nonpharmacological therapy that could reduce blood pressure was decoction of avocado leaves. This study aims to determine effectiveness decoction of avocado leaves to blood pressure of hypertensive patients in Siwalankerto Health Center Surabaya. Methods: This research used Quasy experimental one groups pre test-posttest with control design with a quantitative approach. Sampling techniques used was probability sampling with simple random sampling which obtained sample of 30 respondents aged 26-45 years old.15 respondents in the avocado leaves decoction intervention groups and 15 respondents in the control groups. Data analysis was carried out with the help of computer programs by using Paired T-Test. Result: result of the Paired T-Test of systolic and dyastolic blood pressure obtained $p=0,000$ with a significance level $(p<0,05)$, meaning that there was an influence between before and after giving treatment of avocado leaves decoction to blood pressure of hypertensive patients in Siwalankerto Health Center Surabaya. Conclusion: The research implication showed that complementary therapies provided by nurses could be a motivation to achieve the goals of hypertension self care.
\end{abstract}

\section{Keywords : Avocado leaves, Blood Pressure, Adults}

\begin{abstract}
ABSTRAK
Latar belakang:Hipertensi merupakan penyebab kematian tertinggi di Indonesia. Terapi non farmakologi yang dapat menurunkan tekanan darah adalah rebusan daun alpukat. Tujuan penelitian ini yaitu untuk mengetahui efektifitas rebusan daun alpukat terhadap tekanan darah penderita hipertensi di Puskesmas Siwalankerto Surabaya. Metode: Penelitian ini menggunakan Quasy eksperimen one group pre test-post test with control design dengan pendekatan kuantitatif. Teknik sampling menggunakan probability sampling dengan simple random sampling didapat sampel sejumlah 30 responden usia dewasa 26-45 tahun.15 responden kelompok rebusan daun alpukat dan 15 responden kelompok kontrol. Analisa data dilakukan dengan bantuan program komputer menggunakan uji Paired T-Test. Hasil: uji Paired T-Test tekanan darah sistol dan diastol diperoleh nilai $p=0,000$ dengan tingkat kemaknaan $(p<0,05)$, artinya ada pengaruh antara sebelum dan sesudah pemberian rebusan daun alpukat terhadap tekanan darah penderita hipertensi di Puskesmas Siwalankerto Surabaya. Kesimpulan: Implikasi penelitian menunjukkan terapi komplementer yang diberikan oleh perawat dapat menjadi motivasi untuk mencapai tujuan dari self care hipertensi.
\end{abstract}

Kata Kunci : Daun Alpukat, Tekanan Darah, Usia Dewasa 


\section{PENDAHULUAN}

Hipertensi merupakan salah satu Penyakit Tidak Menular (PTM) yang menjadi permasalahan serius sampai saat ini. Hipertensi umumnya terjadi tanpa gejala. Sebagian besar penderita hipertensi tidak mengetahui dirinya mengidap hipertensi, meski tekanan darahnya sudah jauh diatas normal (WHO, 2014). Berdasarkan data WHO (2015), pada tahun 2025 diperkirakan akan ada 1,5 miliar orang yang terkena hipertensi. Diperkirakan juga setiap tahun terdapat 9,4 juta orang meninggal akibat hipertensi dan komplikasi. Menurut data Dinas Kesehatan Provinsi Jawa Timur (2016), kasus tertinggi PTM di Jawa Timur adalah hipertensi berjumlah 935.736 kasus. Berdasarkan data Dinas Kesehatan Surabaya pada tahun (2015), pengukuran tekanan darah pada pasien diketahui terdapat $16,78 \%$ penderita hipertensi dari 818.331 pasien yang periksa di puskesmas pada tahun 2015 .

Keteraturan penderita hipertensi untuk mengontrol dan juga mengkonsumsi obat anti hipertensi dapat mencegah terjadinya komplikasi, karena hipertensi yang tidak terkontrol dapat meningkatkan komplikasi seperti gagal jantung, stroke, gagal ginjal, dan komplikasi lainnya yang diakibatkan beban jantung dalam memasok kebutuhan darah itu sangat kecil. Oleh karena itu, perlu diadakannya beberapa penanggulangan dalam mencegah meningkatnya penderita hipertensi terutama di usia dewasa berkisar 26-45 tahun,salah satunya dengan cara terapi komplementer menggunakan tumbuhan herbal.

Tumbuhan herbal yang disinyalir dapat menurunkan tekanan darah yaitu dengan menggunakan daun alpukat (Persea Americana Miller). Daun alpukat memiliki kandungan flavonoid yang berfungsi untuk menurunkan tekanan darah. Daun alpukat (Persea Americana Mill) adalah salah satu tanaman yang dapat dimanfaatkan untuk menurunkan tekanan darah (Nessbit, Stein \& Kamas, 2010;Talha, Priyanka \& Akanksha, 2011 dalam Sulistiawati, Prapti \& Lestari, 2015). Kandungan zat aktif yang terdapat di daun alpukat (Persea Americana Miller) adalah flavonoid dan quersetin (Margowati,2014). Daun alpukat mengandung flavonoid, saponin, alkaloid, dan steroid (Sulistiawati A, Ni Ketut \& Made, 2015; Paramawati, 2016).

Salah satu cara kerja daun alpukat adalah mengeluarkan sejumlah cairan dan elektrolit maupun zat-zat yang bersifat toksik. Berkurangnya jumlah air dan garam 
di dalam tubuh maka pembuluh darah akan longgar sehingga tekanan darah perlahan-lahan mengalami penurunan. Efek Zat flavonoid yang terkandung dalam daun alpukat berkhasiat sebagai diuretik. Diuretik berperan dalam mengobati penyakit yang menyebabkan terjadinya penumpukan cairan dalam tubuh. Hal ini berkaitan dengan penyembuhan penyakit tertentu, terutama yang berhubungan dengan penurunan tekanan darah melalui pembuangan air dalam darah pada penyakit hipertensi dan pembuangan zat-zat tertentu pada penyakit ginjal (batu ginjal), asam urat tinggi, hiperkalsemia, dan diabetes insipidus (Paramawati, 2016).

\section{METODE}

Penelitian ini merupakan penelitian kuantitatif yang menggunakan rancangan penelitian Quasy eksperimen one group pre test-post test with control design yang bertujuan untuk mengetahui efektifitas rebusan daun alpukat terhadap tekanan darah penderita hipertensi. Penggunaan daun alpukat untuk hipertensi dengan cara direbus, dengan membuat rebusan sebanyak 5 lembar ( 25 gr) daun alpukat setengah tua berwarna hijau mengkilat yang sudah dikeringkan. Direbus dengan 3 gelas air hingga air menjadi \pm 2 gelas. Angkat dan saring rebusan daun alpukat, lalu dinginkan. Air rebusan daun alpukat dikonsumsi 2x sehari (pagi dan sore hari) dengan dosis 1 gelas 200cc satu kali sehari (hasilnya dibagi menjadi 2 yaitu 100cc rebusan sekali minum) (Margowati, Sigit \& Mita, 2016; Sulistiawati A, Ni Ketut \& Made, 2015). Penelitian ini dilakukan pada tanggal 29 April sampai 5 Mei 2019 di Puskesmas Siwalankerto Surabaya. Populasi dalam penelitian ini adalah responden usia dewasa yang berusia antara 26-45 tahun di Puskesmas Siwalankerto Surabaya berjumlah 51 orang. Sampel dalam penelitian ini didapatkan sampel sebanyak 30 responden. 15 responden kelompok intervensi rebusan daun alpukat dan 15 responden kelompok kontrol. Cara pengambilan sampel pada penelitian ini menggunakan probability sampling dengan pendekatan simple random sampling. Adapun kriteria inklusi pada teknik pengambilan sampel antara lain : (1) Responden hipertensi dengan tekanan darah sistolik 140-170 mmHg dan tekanan darah diastolik diatas $80 \mathrm{mmHg}$. (2) Responden berusia dewasa (2645 tahun). (3) Responden yang kooperatif, (4) Laki-laki dan Perempuan, (5) Responden yang tidak mengkonsumsi obat antihipertensi. Analisa bivariat dalam penelitian ini adalah keterkaitan antara rebusan daun alpukat dengan tekanan darah. 
Setelah kedua data terkumpul selanjutnya di proses untuk menganalisa dengan uji Paired T-Test dengan menggunakan program komputer. Uji Paired T-Test sudah melalui uji normalitas dan didapatkan data berdistribusi normal.

\section{HASIL PENELITIAN}

Tabel 1 Karakteristik Responden Intervensi Rebusan Daun Alpukat Pada Penderita Hipertensi Di Puskesmas Siwalankerto Surabaya

\begin{tabular}{lcccc}
\hline \multicolumn{1}{c}{ Variabel } & \multicolumn{2}{c}{$\begin{array}{c}\text { Intervensi Rebusan Daun } \\
\text { Alpukat }\end{array}$} & \multicolumn{2}{c}{ Kelompok Kontrol } \\
\cline { 2 - 5 } Usia & F & \% & F & \% \\
$26-35$ & 5 & 33,3 & 1 & 6,7 \\
$35-45$ & 10 & 66,7 & 14 & 93,3 \\
& & & & \\
Jenis Kelamin & & 26,7 & 3 & 20,0 \\
Laki-laki & 4 & 73,3 & 12 & 80,0 \\
Perempuan & 11 & & & \\
Pendidikan & & 6,7 & 2 & 13,3 \\
SD & 1 & 26,7 & 2 & 13,3 \\
SMP & 4 & 46,7 & 10 & 66,7 \\
SMA/Sederajat & 7 & 20,0 & 1 & 6,7 \\
Perguruan & 3 & & & \\
Tinggi & & 0 & 0 & 0 \\
Tidak Sekolah & 0 & & & \\
& & 42,9 & 6 & 40,0 \\
Pekerjaan & & 57,1 & 7 & 46,7 \\
Wiraswasta & 6 & 0 & 0 & 0 \\
Ibu Rumah & 9 & 0 & 2 & 13,3 \\
Tangga & & & & \\
Pensiunan & 0 & 0 & &
\end{tabular}

Berdasarkan tabel 1. Menunjukkan bahwa distribusi usia interensi rebusan daun alpukat dan kelompok kontrol paling banyak yaitu usia 45 tahun sebanyak 3 responden $(20,0 \%)$ pada kelompok rebusan daun alpukat, sebanyak 6 responden $(40,0 \%)$ pada kelompok kontrol. Selain usia juga dapat dilihat berdasarkan jenis kelamin paling banyak intervensi rebusan daun alpukat yaitu pada jenis kelamin perempuan sebanyak 11 responden $(73,3 \%)$, sedangkan pada kelompok kontrol paling banyak pada jenis kelamin perempuan sebanyak 12 responden $(80,0 \%)$. Distribusi pendidikan terakhir menunjukkan bahwa kelompok intervensi rebusan daun alpukat paling banyak yaitu responden pada pendidikan SMA/sederajat sebanyak $7(46,7 \%)$, tidak berbeda pada kelompok kontrol paling banyak pada 
responden dengan pendidikan SMA/Sederajat sebanyak 10 (66,7\%). Distribusi pekerjaan menunjukkan bahwa kelompok intervensi rebusan daun alpukat sebagian besar memiliki pekerjaan sebagai ibu rumah tangga berjumlah 9 responden $(57,1 \%)$, sedangkan pada kelompok kontrol sebagian besar memiliki pekerjaan sebagai ibu rumah tangga berjumlah 7 responden $(46,7 \%)$.

Tabel 2 Hasil Uji Paired T-Test Hasil Pengukuran Tekanan Darah Sistolik penderita Hipertensi Sebelum (Pre Test) dan Sesudah (Post Test) di Puskesmas Siwalankerto Surabaya 29 April-5 Mei dengan Jumlah Responden (N=30)

\begin{tabular}{lcccc}
\hline \multicolumn{1}{c}{ Tekanan Darah } & $\mathrm{N}$ & $\begin{array}{c}\text { Mean } \\
\text { Pre Test }\end{array}$ & $\begin{array}{c}\text { Mean } \\
\text { Post Test }\end{array}$ & P Value \\
\hline $\begin{array}{l}\text { Kelompok rebusan } \\
\text { daun alpukat }\end{array}$ & 15 & 153,00 & 123,00 & 0,000 \\
Kelompok kontrol & 15 & 155,33 & 151,33 & 0,138 \\
\hline
\end{tabular}

Berdasarkan tabel 2. Menunjukkan bahwa pengukuran tekanan darah sistolik post test kelompok rebusan daun alpukat didapatkan nilai $P$ Value sebesar $0,000(<0,05)$, maka H0 ditolak Ha diterima sehingga dapat disimpulkan bahwa terdapat perbedaan rata-rata tekanan darah sistolik pre test dan post test pada kelompok rebusan daun alpukat, sedangkan untuk kelompok kontrol didapatkan nilai $P$ Value sebesar 0,138 (>0,05), maka H0 diterima Ha ditolak sehingga dapat disimpulkan bahwa tidak ada perbedaan tekanan darah sistolik pre test dan post test pada kelompok kontrol.

Tabel 3 Hasil Uji Paired T-Test Hasil Pengukuran Tekanan Darah Diastolik pada Penderita Hipertensi Sebelum (Pre Test) dan Sesudah (Post Test) di Puskesmas Siwalankerto Surabaya 29 April-5 Mei dengan Jumlah Responden (N=30)

\begin{tabular}{lcccc}
\hline \multicolumn{1}{c}{ Tekanan Darah } & $\mathrm{N}$ & $\begin{array}{c}\text { Mean } \\
\text { Pre Test }\end{array}$ & $\begin{array}{c}\text { Mean } \\
\text { Post Test }\end{array}$ & P Value \\
\hline $\begin{array}{l}\text { Kelompok rebusan } \\
\text { daun alpukat }\end{array}$ & 15 & 94,67 & 73,33 & 0,000 \\
Kelompok kontrol & 15 & 87,33 & 82,60 & 0,024 \\
\hline
\end{tabular}

Berdasarkan tabel 3 Menunjukkan bahwa kelompok rebusan daun alpukat didapatkan nilai $P$ Value sebesar $0,000(<0,05)$, maka H0 ditolak Ha diterima sehingga dapat disimpulkan bahwa terdapat perbedaan rata-rata tekanan darah diastolik pre test dan post test pada kelompok rebusan daun alpukat, sedangkan untuk kelompok kontrol didapatkan nilai $P$ Value sebesar 0,024 $(<0,05)$, maka H0 
ditolak Ha diterima sehingga dapat disimpulkan bahwa ada perbedaan tekanan darah diastolik pre test dan post test pada kelompok kontrol.

\section{PEMBAHASAN}

\section{Tekanan Darah Responden Sebelum dan Sesudah Diberikan Intervensi Rebusan Daun Alpukat}

Kejadian hipertensi terus meningkat setiap tahunnya dan masalah yang sering terjadi pada pasien hipertensi adalah ketidakpatuhan terapi atau pengobatan, merubah gaya hidup, dan adanya komplikasi akibat hipertensi. Salah satu faktor yang berperan dalam hal ini disebabkan oleh self care yang kurang baik. Pasien hipertensi sering diikuti dengan ketidaksanggupan pasien tersebut dalam melakukan self care secara mandiri. Ketidaksanggupan pasien hipertensi dalam melakukan self care dapat mempengaruhi kualitas hidup dari segi kesehatan fisik, kesejahteraan psikologis, hubungan sosial, dan hubungan dengan lingkungan. Self care yang dilakukan pada penderita hipertensi lebih dititik beratkan pada pencegahan komplikasi dan pengontrolan pola makan yang mengandung garam dan lemak.

Berdasarkan hasil penelitian secara umum tentang pemberian rebusan daun alpukat terhadap tekanan darah pada penderita hipertensi di Puskesmas Siwalankerto Surabaya didapatkan sebanyak 15 orang mengalami perubahan tekanan darah yang signifikan setelah diberikan rebusan daun alpukat.

Berdasarkan kelompok intervensi rebusan daun alpukat sebanyak 15 orang saat dilakukan pengukuran tekanan darah sebelum dilakukan intervensi menunjukkan nilai sistolik didapatkan rata-rata $153,00 \mathrm{mmHg}$ dengan nilai tekanan darah tertinggi $170 \mathrm{mmHg}$ dan terendah $140 \mathrm{mmHg}$ dan tekanan darah diastolik didapatkan rata-rata 94,67 $\mathrm{mmHg}$ dengan nilai tekanan darah tertinggi $110 \mathrm{mmHg}$ dan terendah $80 \mathrm{mmHg}$. Hasil tersebut menunjukkan bahwa masyarakat usia dewasa membutuhkan pengobatan farmakologi dan non farmakologi dengan menggunakan rebusan daun alpukat dalam menurunkan tekanan darah harus segera dilakukan di Puskesmas Siwalankerto Surabaya.

Berdasarkan hasil dari pemeriksaan tekanan darah pada kelompok rebusan daun alpukat sebanyak 15 responden, menunjukkan tingginya tekanan darah sistolik 170 
mmHg sebanyak 2 orang, dikarenakan responden suka mengkonsumsi makanan bercita rasa asin. Responden yang sering mengkonsumsi makanan bercita rasa asin lebih dari (1x sehari) sebanyak 14 responden, jarang mengkonsumsi (1-5x/minggu) sebanyak 1 responden.

Hasil dari penelitian tersebut, maka hipertensi dipengaruhi oleh makanan bercita rasa asin. Makanan yang mengandung garam merupakan faktor resiko terjadinya hipertensi pada orang dewasa. Proses metabolisme tubuh, garam yang dikonsumsi sebagian besar akan diserap oleh usus dan dibuang kembali oleh ginjal melalui urin. Apabila jumlah garam yang dikonsumsi melebihi kapasitas ginjal untuk bekerja mengeluarkannya kembali, maka kadar natrium dalam darah akan meningkat, dan untuk menormalkannya kembali cairan intraseluler harus ditarik keluar sehingga volume ekstrasluler meningkat. Meningkatnya volume cairan ekstraseluler tersebut menyebabkan meningkatnya volume darah, sehingga berdampak pada timbulnya hipertensi (Manikome et al.,2016).

Pada pemeriksaan tekanan darah sesudah diberikan rebusan daun alpukat, menunjukkan tekanan darah sistolik rata-rata 123,00 $\mathrm{mmHg}$ dengan nilai tertinggi $140 \mathrm{mmHg}$ dan terendah $105 \mathrm{mmHg}$ dan tekanan darah diastolik 73,33 $\mathrm{mmHg}$ dengan nilai tertinggi $90 \mathrm{mmHg}$ dan terendah $60 \mathrm{mmHg}$.

Hasil penelitian ini diperkuat dengan hasil pengujian statistik yang berfungsi untuk mengetahui ada atau tidaknya penurunan tekanan darah sebelum dan sesudah pemberian intervensi rebusan daun alpukat yaitu dengan uji Paired $T$ Test di peroleh nilai $P$ Value sebesar $0,000(<0,05)$. Hasil penelitian menunjukkan adanya perbedaan sebelum dan sesudah pemberian rebusan daun alpukat terhadap tekanan darah pada penderita hipertensi.

Hasil ini sejalan dengan penelitian Margowati, S (2016) bahwa hasil uji statistik diperoleh nilai $P$ Value sebesar $0,004(<0,05)$. Hal ini menunjukkan terdapat pengaruh pemberian seduhan daun alpukat dalam menurunkan tekanan darah sistolik maupun diastolik sebelum dan setelah dilakukan intervensi. Menurut Arukwe (2012) kandungan zat aktif terbanyak pada daun alpukat yaitu zat flavonoid sebanyak 8,11 $\pm 0,14 \mathrm{mg}$. Flavonoid pada daun alpukat memiliki fungsi menurunkan tekanan darah. Mekanisme kerja flavonoid dapat melancarkan peredaran darah dan mencegah terjadinya penyumbatan pembuluh darah, sehingga darah dapat mengalir 
dengan normal. Flavonoid juga mengurangi kandungan kolesterol serta mengurangi penimbunan lemak pada dinding pembuluh darah. Daun alpukat bekerja dengan mengeluarkan sejumlah cairan dan elektrolit maupun zat-zat yang bersifat toksik. Jika jumlah air dan garam dalam tubuh berkurang maka pembuluh darah akan longgar sehingga tekanan darah perlahan-lahan mengalami penurunan.

Peran mandiri perawat dalam membantu menurunkan tekanan darah dengan cara memberikan edukasi dan promosi kesehatan pada pasien dan keluarga terkait terapi komplementer. Perawat dalam menjalankan peran edukator untuk membantu pasien dalam meningkatkan kesehatan, mempertahankan kesembuhan pasien hipertensi. Semakin baik perawat memberikan pendidikan kesehatan kepada pasien, maka kepatuhan dan anjuran responden dalam melakukan sesuatu untuk menurunkan tekanan darah akan semakin tinggi.

\section{KESIMPULAN}

Hasil penelitian ini menunjukkan terdapat pengaruh antara rata-rata tekanan darah sistolik dan diastolik sebelum dan sesudah pemberian rebusan daun alpukat. Sehingga dapat disimpulkan bahwa terapi komplementer dengan menggunakan rebusan daun alpukat dapat menurunkan tekanan darah penderita hipertensi di Puskesmas Siwalankerto Surabaya. Daun alpukat lebih efektif untuk menurunkan tekanan darah penderita hipertensi.

\section{SARAN}

Diharapkan dapat terus memberikan penyuluhan kesehatan dan memberikan pendidikan kesehatan kepada usia dewasa muda dan lansia mengenai pentingnya hidup sehat dan dapat menjadikan penelitian ini sebagai salah satu terapi non farmakologi dalam hal menurunkan tekanan darah pada usia dewasa dengan hipertensi.

\section{DAFTAR PUSTAKA}

A rukwe U, Amadi BA, Duru MK. 2012. "Chemical Composition of Persea Americana Leaf, Fruit and Seed." IJRRAS 2: 346-49

Asmar. 2019. "Intervensi Cutaneous Stimulation Untuk Menurunkan Analisis 
Praktik Klinik Keperawatan Dengan Inovasi Intervensi Cutaneous Stimulation Untuk Menurunkan Nyeri Pemasangan Infus Padaklien Hipertensi Di Ruang Instalasi Gawat Darurat RSUD Abdul Wahab Sjahranie."

Depkes RI. 2009. Departemen Kesehatan Republik Indonesia.

Dinas Kesehatan Kota Surabaya. 2015. "Dinas Kesehatan Kota Surabaya."

Dinkes. 2016. Provinsi Jawa Timur, Dinkes Profil Kesehatan Provinsi Jawa Timur Tahun 2016 [East Java Health Profile 2016].

Khotimah, N. 2018. "Model Peningkatan Kepatuhan Gaya Hidup Sehat Pada Pasien Hipertensi Berbasis Social Cognitive Theory Di Wilayah Kerja Puskesmas Kota Bima." Tesis.

Manikome, et al.2016. Gambaran Konsumsi Makanan Laut PenderitaHipertensi Di Wilayah Kerja Puskesmas Dagho Kecamatan Tamako. ejournal keperawatan. Vol.4 No.1.

Margowati S, Sigit \& Wiharyani. 2016. "Efektivitas Pengunaan Rebusan Daun Alpukat Dengan Rebusan Daun Salam Dalam Penurunan Tekanan Darah Pada Lansia." : 234-48.

Paramawati, R., \& Dumilah, D.R. 2016. Khasiat Ajaib Daun Avokad. Jakarta: Penebar Swadaya.

Sulistiawati, Ni Ketut \& Made pande.2015. Pengaruh Pemberian Air Rebusan Daun Alpukat (Persea Americana Mill.) Terhadap Tekanan Darah Pasien Hipertensi Di Wilayah Kerja Puskesmas II Denpasar Selatan. COPING Ners Journal."Vol.03, No.3 Diakes September -Desember 2015.

WHO. 2014. Hypertension Fact Sheet. World Health Organization. Geneva.

WHO. 2015. Hypertension Fact Sheet. World Health Organization. Geneva. 